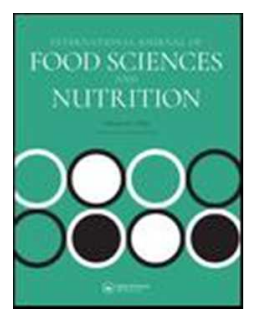

\title{
POOR EARLY GROWTH AND HIGH SALT INTAKE IN INDIAN INFANTS
}

\begin{tabular}{|r|l|}
\hline Journal: & International Journal of Food Sciences and Nutrition \\
\hline Manuscript ID & CIJF-2016-0672.R1 \\
\hline Manuscript Type: & Research Paper \\
\hline Date Submitted by the Author: & n/a \\
\hline Complete List of Authors: & $\begin{array}{l}\text { Genovesi, Simonetta; University of Milano-Bicocca , Department of } \\
\text { Medicine and Surgery; Azienda Ospedaliera San Gerardo } \\
\text { Antolini, Laura; University of Milano-Bicocca, Department of Medicine and } \\
\text { Surgery, Centre of Biostatistics for Clinical Epidemiology } \\
\text { Orlando, Antonina; University of Milano-Bicocca } \\
\text { Brahmochary Mandal , Sujit; Institute for Indian Mother and Child } \\
\text { De Servi, Alessandra; Project for People } \\
\text { Capelli, Silvia; Project for People } \\
\text { Giussani, Marco; Family Paediatrician } \\
\text { Nava, Elisa; University of Milano-Bicocca } \\
\text { Agostoni, Carlo; University of Milan, Clinical Sciences and Community } \\
\text { Health; IRCCS Ca' Granda, Ospedale Maggiore Policlinico, Pediatric Clinic } 2 \\
\text { Gallieni, Maurizio; ASST Santi Paolo e Carlo, University of Milano, } \\
\text { Nephrology and Dialysis Unit }\end{array}$ \\
\hline Keywords: & \begin{tabular}{l} 
Salt, India, Growth, hypertension, Infants, Nutrition \\
\hline
\end{tabular} \\
\hline
\end{tabular}




\section{POOR EARLY GROWTH AND HIGH SALT INTAKE IN INDIAN INFANTS}

2 Genovesi Simonetta ${ }^{\mathrm{a}, \mathrm{b}}$, Antolini Laura ${ }^{\mathrm{c}}$, Orlando Antonina ${ }^{\mathrm{a}}$, Brahmochary Sujit ${ }^{\mathrm{d}}$, De Servi 3 Alessandra $^{\mathrm{e}}$, Capelli Silvia ${ }^{\mathrm{e}}$, Giussani Marco ${ }^{\mathrm{f}}$, Nava Elisa ${ }^{\mathrm{a}}$, Agostoni Carlo ${ }^{\mathrm{g}}$, Gallieni Maurizio ${ }^{\mathrm{e}, \mathrm{h}}$.

4

5

6

Affiliations

${ }^{a}$ Department of Medicine and Surgery, University of Milano-Bicocca and Nephrology Unit, San Gerardo Hospital, Monza, Italy

${ }^{\mathrm{b}}$ Department of Cardiovascular, Neural and Metabolic Sciences, Istituto Auxologico Italiano, Milan, Italy

${ }^{c}$ Department of Medicine and Surgery, Centre of Biostatistics for Clinical Epidemiology, University of Milano-Bicocca, Monza, Italy

${ }^{\mathrm{d}}$ Institute for Indian Mother and Child (IIMC), Kolkata, India

${ }^{\mathrm{e}}$ Project for People, Milan, Italy

${ }^{\mathrm{f}}$ Family Paediatrician, Milano, Italy

${ }^{g}$ Pediatric Clinic, Department of Clinical Sciences and Community Health, University of Milan, Fondazione IRCCS Ca' Granda - Ospedale Maggiore Policlinico, Milan, Italy

${ }^{\mathrm{h}}$ Nephrology and Dialysis Unit, Ospedale San Carlo Borromeo, ASST Santi Paolo e Carlo, Department of Biomedical and Clinical Sciences 'L. Sacco', University of Milan, Italy

Email Addresses: Simonetta Genovesi simonetta.genovesi@unimib.it; Laura Antolini laura.antolini@unimib.it; Sujit Brahmochary iimcmission@gmail.com; Alessandra De Servi alessandra deservi@alice.it; Silvia Capelli silvi.capelli@yahoo.it; Marco Giussani abrjg@tin.it; Antonina Orlando antonina.orlando@,unimib.it; Elisa Nava elisa.nava4@virgilio.it; Carlo Agostoni carlo.agostoni@unimi.it; Maurizio Gallieni maurizio.gallieni@fastwebnet.it

Corresponding author: Dr. Maurizio Gallieni

Nephrology and Dialysis Unit, Ospedale San Carlo Borromeo, ASST Santi Paolo e Carlo, Univeristy of Milano

Via Pio II, 3 - 20153 Milano, Italy

tel: +39 0240222445 - ORCID 0000-0002-2011-2160

Email: maurizio.gallieni@fastwebnet.it

Keywords: Infant, Growth, Nutrition, Hypertension, Salt, India. 
37 ABSTRACT

38 The influence of feeding patterns on the growth of infants and how salt is included in the diet are 39 unknown in the area of West Bengal, India. A cross-sectional study was carried on 517 infants 40 (median age 6.5 months). Negative Z-scores were observed for all anthropometric parameters. $4172.7 \%$ of infants aged 0-6 months received exclusive breastfeeding. In the 6-12 month-old group $42(\mathrm{n}=235), 91.5 \%$ had salt added to foods. In a regression model adjusted for age, a low salt diet 43 resulted a significant factor in increasing weight-for-length and BMI-for-age z-scores, with 44 increments equal to $0.637 \mathrm{SD}(\mathrm{p}=0.037)$ and $0.650 \mathrm{SD}(\mathrm{p}=0.036)$, respectively.

45 In West Bengal infants showing poor growth, breastfeeding was associated with better 46 anthropometric indexes, but early in life salt is added to their diet. Early life low weight coupled 47 with high salt intake may be a risk factor for arterial hypertension in Indian children. 


\section{INTRODUCTION}

50 According to the World Health Organization, non-communicable chronic diseases, including 51 hypertension and kidney disease, are the most relevant public health problems worldwide, also in 52 developing countries (WHO/FAO, 2002). Recent studies from our group showed a high prevalence 53

\section{METHODS}

IIMC health care workers and international volunteers collected data on the health status of infants and mothers. We studied 517 babies from 11 centers of aforementioned area, from January to 
83 March 2013. Their median age was 6.5 months (interquartile range $=3.1-9.2$, range $=1-12$ ), and $48.6 \%$ were females babies. A team composed of doctors, nurses, health workers and international medical students participated in the screening procedures. Visits and measurements were carried out in IIMC owned medical ambulatory structures or schools, adapted as day-clinics (Figure 1). The children nutritional status was assessed by a dietary questionnaire, administered to mothers by experienced nutritionist at the time of children visit, and consisting of two parts. The first part related to children demographic data (name, surname, gender and date of birth). The second part related to two periods of child feeding: lactation and complementary feeding. Information about lactation concerned breastfeeding and its duration and the possible intake of other types of milk (cow's milk or formula). Information about introduction of complementary foods concerned type and time of introduction. Specific questions about adding further salt to food and "adult food" intake were also provided. Anthropometric characteristics of the sample were assessed by measuring length and weight with an infantometer and mobile digital scale (SECA, Vogel \& Halke GmbH, Hamburg, Germany).

No formal evaluation and approval of the study protocol was obtained by an ethics committee, for the following reasons: the study was conducted in a very poor suburban/rural area in Kolkata suburbs as part of the regular volunteer activities of IIMC in support of poor mothers and children without access to medical care; IIMC is a NGO institution without an internal ethics committee; the study was observational and no drugs or diagnostic tests were administered to the studied subjects. Nevertheless, mothers gave their consent for the study participation and the study was conducted following the principles and guidelines in the World Medical Association (2000) Declaration of Helsinki on medical research involving human subjects (http://www.wma.net/en/30publications/10policies/b3/). No human subject included in this study can be identified via the paper; data were fully anonymized.

The study population was partitioned into 3 age groups: 0 (1day)-3 completed months, 3 ( 3 months +1 day)- 6 completed months, 6 ( 6 months +1 day)-12 completed months. The impact on growth of exclusive breastfeeding versus not exclusive breastfeeding was evaluated in the first two age groups. Babies aged 6-12 completed months were analyzed to evaluate the impact of solid food introduction.

Raw anthropometric measures were processed by calculating the gender-specific z-score of lengthfor-age, weight-for-length, body mass index (BMI)-for-age, and weight-for-age, according to the World Health Organization charts (de Onis and Yip, 1996). Calculating z-score converts anthropometric measurements in the number of standard deviations the observed value is far from the expected median value in the reference population. Z-score values were subsequently 
117 categorized into $<-3$ standard deviations, within -3 and -2 standard deviations, within -2 and -1 standard deviations for the definition of poor growth (WHO, 2009) as follows:

\section{Statistical analysis}

Anthropometric measures and z-score distributions were described graphically by box-plot graphs and by the summary measures mean, standard deviation, median and the 0.25 and 0.75 quantiles. Distributions were compared across age groups by $\mathrm{F}$ test and Bonferroni correction for post-hoc pairwise comparisons. Percentages of $z$-score $<-3$, within -3 and -2 , within -2 and -1 standard deviations were represented graphically by bar-plot graphs. Percentages of z-score $<-1$, as overall percentages of poor growth, were compared across age groups by Chi-square test. The dependence between the z-score distributions and exclusive vs non exclusive breastfeeding, salt consumption vs non consumption, adult food consumption vs non consumption were investigated in regression models adjusted for age.

\section{RESULTS}

Table 1 describes anthropometrics characteristics according to age group, which are represented by box-plots in Figure 2. Length-for-age z-score showed, in all age groups, negative mean values with a mild, non-significant worsening trend over time. When considering standardized measures of weight with respect to the achieved length, namely weight-for-length $\mathrm{z}$-score and the BMI-for-age z-score, negative mean values were observed in all age groups. For both, weight-for-length z-score and BMI-for-age z-score, there was a sensible difference across age groups with a tendency to improve growth from 0-3 months to 3-6 months. A subsequent flexion at 6-12 months was observed only for weight-for-length z-score. Negative averages were observed in all age groups for weight-

144 Table 2 describes the percentages of severe, moderate and mild poor growth showing that about $14550 \%$ of children aged 0-3 months showed poor growth for all parameters. For stunting (length-for146 age z-score) and wasting (weight-for-length z-score) no significant differences were observed 147 across age groups, whereas the percentage of moderate and severe BMI-for-age $z$-score alterations 148 significantly decreased with increasing age. A similar trend was observed for under weight (weight149 for-age z-score) from 0-3 months to 3-6 months. When considering only severe and moderate poor 
150 growth, the overall percentages were about $20 \%$ for all parameters with the exception of wasting 151 (weight-for-length z-score), which was more modest.

152 The analysis of dietary habits showed that $72.7 \%$ of the 238 babies aged $0-6$ months received 153 exclusive breastfeeding, a further $25.2 \%$ received mixed feeding, and thus only $2.1 \%$ artificial 154 feeding. When contrasting mixed breastfeeding versus exclusive breastfeeding a modest non155 significant tendency to increase was observed for all parameters (i.e. observed averages for weight156 for-length $\mathrm{z}$-score were -0.69 and $-0.62, \mathrm{p}=0.676$ ), even when adjusting for age.

157 Considering the 6-12 months group ( $\mathrm{n}=235$ babies), we observed that $91.5 \%$ ( $\mathrm{n}=215$ babies) had 158 salt added to foods and the majority of them $(n=209 / 215,97.2 \%)$ started at six completed months. 159 In a regression model adjusted for age, not having added salt resulted a significant factor in 160 increasing weight-for-length z-score and BMI-for-age z-score, with increments equal to 0.637 SD $161(\mathrm{p}=0.0373)$ and $0.650 \mathrm{SD}(\mathrm{p}=0.0360)$ respectively (Table 3). No significant relationships were 162 observed for length-for-age z-score and weight-for-age z-score.

163 Among infants fed adult foods, most ingested "kitchuri", consisting of rice, lentils, vegetables, 164 chicken or fish with added salt, cornmeal, sugar and fried oil. The percentage of infants fed adult 165 foods starting at 6 months of life was 79.2\%. A regression model adjusted for age showed that 166 infants not assuming adult food had higher weight-for-length and BMI-for-age z-scores, with 167 increment equal to $0.560 \mathrm{SD}(\mathrm{p}=0.0071)$ and $0.589 \mathrm{SD}(\mathrm{p}=0.0051)$ (Table 4).

168 Further differences were not detectable in infants fed other types of solids, such as flour, biscuits, 169 vegetables, fruits, meat and fish.

170

\section{DISCUSSION}

172 In this population, there was a high prevalence of malnutrition, in particular in the first three months 173 of life, as suggested by anthropometric parameters. Unfortunately, the analysis could not be 174 adjusted for infants' birth weight since the delivery occurred at home where weighing the newborn 175 is still an unusual practice. However, considering the rates of malnutrition observed in the youngest 176 group, a high prevalence of low birth weight for gestational age may be hypothesized. A low 177 intrauterine growth would lead to increased insulin resistance, according to Barker hypothesis, 178 (Barker et al 2010). In addition, insulin increase is associated with higher blood pressure values also 179 in children (Genovesi et al. 2012). We found a high percentage of breastfeeding mothers and the 180 breastfeeding practice was associated with an improvement of all anthropometric indexes of infants, 181 underscoring the importance of encouraging breastfeeding even in low income countries. The 182 complementary feeding period shows some peculiar characteristics. A high percentage of infants 183 have salt added to foods quite early. Salt intake starting in the pediatric age is associated to a high 
184 prevalence of arterial hypertension (Whitten et al. 1980, Hofman et al. 1983, Pomeranz et al. 2002, 185 He et al. 2006, Strazzullo et al. 2012) and we speculate that this evidence could at least partly 186 explain the high prevalence of hypertension observed in our previous investigations in the West 187 Bengal region (Gallieni et al. 2013, Genovesi et al. 2011). Infants who received added salt showed 188 also lower body weight measures standardized for height than those who did not. This association 189 was observed even in those 6 to 12 month-old infants fed the kitchuri food. While the biologic 190 plausibility of high salt intake and lower body weight is unclear, it has already been observed both 191 experimentally (Coelho et al. 2006) and clinically in children (Stein et al. 2006), suggesting some 192 hormone-mediated mechanisms. This unusual salt consumption coupled with early low weight 193 conditions may contribute to the early development of arterial hypertension (Calkins et al. 2011). 194 However, because the results of this study do not include a long term evaluation of blood pressure, 195 the effects of increased salt intake during infancy on the prevalence of hypertension in Indian 196 children remain hypothetical.

197 In conclusion, the nutritional pattern of West Bengal babies can be considered adequate only in the 198 0-6 months period, when exclusive breastfeeding is common. Breastfeeding practice prevents the 199 development of infections and dysentery causing underweight or mortality, and is therefore 200 particularly important. However, the complementary feeding period in this population ensues in a 201 critical time, because the early intake of added salt and adult food may have a negative effect on 202 growth and later health, if coupled with the major risk of unfavorable programming associated with 203 intrauterine growth retardation (Keijzer et al. 2005). The results of this study may be used for 204 informing mothers of the importance of continuing breastfeeding as well as retarding the 205 introduction of salt in their babies' diet.

206

207 Geolocation information.

208 This study was undertaken in West Bengal, India 209 210 Acknowledgments

211 Funding: this research was carried on without specific funding. The authors acknowledge all the 212 Indian and International volunteers working at the Institute for Indian Mother and Child, Kolkata, 213 India, who contributed to the collection of data.

214

\section{Declaration of interests statement}

216 The authors report no conflicts of interest. 
218

219

220

221

222

223

224

225

226

227

228

229

230

231

232

233

234

235

236

237

238

239

240

241

242

243

244

245

246

247

248

249

250

\section{References}

Agostoni C, Baselli L, Mazzoni MB. 2013. Early nutrition patterns and diseases of adulthood: A plausible link? Eur J Intern Med. 24:5-10.

Barker DJ, Gelow J, Thornburg K, Osmond C, Kajantie E, Eriksson JG. 2010. The early origins of chronic heart failure: impaired placental growth and initiation of insulin resistance in childhood. Eur J Heart Failure. 12: 819-825.

Calkins K, Devaskar S. 2011. Fetal origins of adult disease. Curr Probl Pediatr Adolesc Health Care. 41:158-176.

Coelho MS, Passadore MD, Gasparetti AL, Bibancos T, Prada PO, Furukawa LL, Furukawa LN, Fukui RT, Casarini DE, Saad MJ, et al. 2006. High- or low-salt diet from weaning to adulthood: effect on body weight, food intake and energy balance in rats. Nutr Metab Cardiovasc Dis. 16:148-155.

Cooper R, Soltero I, Liu K, Berkson D, Levinson S, Stamler J. 1980. The association between urinary sodium excretion and blood pressure in children. Circulation. 62:97-104.

de Onis M, Yip R. 1996. The WHO growth chart: historical considerations and current scientific issues. Bibl Nutr Dieta. 53:74-89.

He FJ, MacGregor GA. 2006. Importance of salt in determining blood pressure in children: meta-analysis of controlled trials. Hypertension. 48:861-869.

Hofman A, Hazebroek A, Valkenburg HA. 1983. A randomized trial of sodium intake and blood pressure in newborn infants. JAMA. 250:370 -373.

Gallieni M, Ene-Iordache B, Aiello A, Tucci B, Sala V, Brahmochary Mandal SK, Doneda A, Stella A, Carminati S, Perico N, Genovesi S. 2013. Hypertension and kidney function in an adult population of West Bengal, India: role of body weight, waist circumference, proteinuria and rural area living. Nephrology. 18:798-807.

Gallieni M, Aiello A, Tucci B, Sala V, Brahmochary Mandal SK, Doneda A, Genovesi S. 2014 The burden of hypertension and kidney disease in Northeast India: the Institute for Indian Mother and Child noncommunicable diseases project. Scientific World Journal. 2014:320869.

Genovesi S, Antolini L, Gallieni M, Aiello A, Mandal SK, Doneda A, Giussani M, Stella A, Tucci B, Valsecchi MG. 2011. High prevalence of hypertension in normal and underweight Indian children. J Hypertens. 29:217-221.

Genovesi S, Brambilla P, Giussani M, Galbiati S, Mastriani S, Pieruzzi F, Stella A, Valsecchi MG, Antolini L. 2012. Insulin resistance, pre-hypertension, hypertension and blood pressure values in paediatric age. J Hypertension. 30:327-335. 
Geleijnse JM, Hofman A, Witteman JC, Hazebroek AA, Valkenburg HA, Grobbee DE 1997. 252 Long-term effects of neonatal sodium restriction on blood pressure. Hypertension. 29:913-917.

253

254

255

256

257

258

259

260

261

262

263

264

265

266

267

268

269

270

271

272

273

274

275

276

277

278

279

280

281

282 Keijzer-Veen MG, Schrevel M, Finken MJ, Dekker FW, Nauta J, Hille ET, Frölich M, van der Heijden BJ; Dutch POPS-19 Collaborative Study Group. 2005. Microalbuminuria and lower glomerular filtration rate at young adult age in subjects born very premature and after intrauterine growth retardation. J Am Soc Nephrol. 16:2762-2768.

Pomeranz A, Dolfin T, Korzets Z, Eliakim A, Wolach B. 2002. Increased sodium concentrations in drinking water increase blood pressure in neonates. J Hypertens. 20:203-207.

Stein LJ, Cowart BJ, Beauchamp GK. 2006. Salty taste acceptance by infants and young children is related to birth weight: longitudinal analysis of infants within the normal birth weight range. Eur J Clin Nutr. 60:272-279.

Strazzullo P, Campanozzi A, Avallone S. 2012. Does salt intake in the first two years of life affect the development of cardiovascular disorders in adulthood? Nutr Metab Cardiovasc Dis. 22:787-792.

White SL, Perkovic V, Cass A, Chang CL, Poulter NR, Spector T, Haysom L, Craig JC, Salmi IA, Chadban SJ, Huxley RR. 2009. Is low birth weight an antecedent of CKD in later life? A systematic review of observational studies. Am J Kidney Dis. 54:248-261.

Whitten CF, Stewart RA. 1980. The effect of dietary sodium in infancy on blood pressure and related factors. Studies of infants fed salted and unsalted diets for five months at eight months and eight years of age. Acta Paediatr Scand Suppl. 279:1-17.

WHO/FAO (2002) Diet, nutrition and the prevention of chronic diseases: report of a joint WHO/FAO expert consultation. Available from: http://www.who.int/dietphysicalactivity/publications/trs916/en/ (accessed June 2016).

WHO (2009) Child Growth Standards and the Identification of Severe Acute Malnutrition in Infants and Children: A Joint Statement by the World Health Organization and the United Nations Children's Fund. 2009 Geneva. Available from: http://www.ncbi.nlm.nih.gov/books/NBK200775/ (accessed June 2016).

$\mathrm{Wu}$ TC, Chen PH. 2009. Health consequences of nutrition in childhood and early infancy. Pediatr Neonatol. 50:135-142. 
283 Table 1. Descriptive statistics of anthropometric characteristics (raw and z-score) according to age 284 group

285

286 287 288 289 290 291 292 293

\begin{tabular}{|c|c|c|c|c|c|c|c|c|c|c|c|c|c|c|c|c|}
\hline \multirow[t]{2}{*}{$\begin{array}{c}\text { Continuous } \\
\text { variable }\end{array}$} & \multicolumn{5}{|c|}{ 0-3 months ( $n=124 ; 24.0 \%)$} & \multicolumn{5}{|c|}{ 3-6 months ( $n=131 ; 25.3 \%)$} & \multicolumn{6}{|c|}{ 6-12 months ( $n=262 ; 50.7 \%)$} \\
\hline & mean & SD & median & $\mathrm{q} 25$ & q75 & mean & SD & median & $\mathrm{q} 25$ & q75 & mean & SD & median & $\mathrm{q} 25$ & q75 & $\mathrm{p}$-value \\
\hline Length $(\mathrm{cm})$ & 54.5 & 3.5 & 54.5 & 52.0 & 57.0 & 61.1 & 3.4 & 61.0 & 59.5 & 63.0 & 68.2 & 4.1 & 68.0 & 65.0 & 71.0 & $<0.0001$ \\
\hline Weight (kg) & 4.2 & 0.8 & 4.2 & 3.6 & 4.7 & 6.0 & 1.0 & 5.9 & 5.4 & 6.6 & 7.5 & 1.1 & 7.4 & 6.7 & 8.1 & $<0.0001$ \\
\hline BMI $\left(\mathrm{kg} / \mathrm{m}^{2}\right)$ & 13,8 & 1.6 & 13.9 & 12.5 & 15.1 & 16.0 & 1.6 & 16.0 & 14.9 & 16.8 & 16.0 & 1.8 & 15.8 & 14.9 & 16.9 & $<0.0001$ \\
\hline $\begin{array}{l}\text { Length for age } \\
\text { (z-score) }\end{array}$ & -1.01 & 1.43 & $\mid-1.02$ & -1.89 & -0.16 & -1.09 & 1.38 & \begin{tabular}{|l|}
-1.14 \\
\end{tabular} & -1.86 & -0.29 & $\begin{array}{l}-1.32 \\
\end{array}$ & 1.43 & -1.21 & -2.09 & -0.52 & 0.0864 \\
\hline $\begin{array}{l}\text { Weight for length } \\
(z \text {-score }) * A\end{array}$ & -0.88 & 1.24 & \begin{tabular}{|c|c|}
-0.97 \\
\end{tabular} & -1.54 & -0.11 & -0.43 & 1.13 & 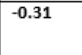 & -1.21 & 0.27 & -0.71 & 1.28 & -0.79 & -1.44 & 0.05 & 0.0115 \\
\hline $\begin{array}{l}\text { BMI for age } \\
\text { (z-score)* }\end{array}$ & -1.32 & 1.13 & -1.18 & -1.89 & -0.66 & -0.72 & 1.16 & \begin{tabular}{|l|}
-0.55 \\
\end{tabular} & -1.39 & -0.04 & -0.73 & 1.29 & -0.81 & -1.47 & 0.01 & $<0.001$ \\
\hline $\begin{array}{l}\text { Weight for age } \\
\text { (z-score)* }\end{array}$ & -1.17 & 1.27 & -1.09 & -1.88 & -0.48 & -0.81 & 1.23 & \begin{tabular}{|l|l|}
-0.77 & \\
\end{tabular} & -1.28 & -0.02 & -0.90 & 1.14 & -0.88 & -1.67 & -0.11 & 0.0474 \\
\hline
\end{tabular}

0-3 months $=$ from 1 day to 3 completed months, 3-6 months $=$ from 3 months +1 day to 6 completed months, $6-12$ months $=$ from 6 months +1 day to 12 completed months, $\mathrm{BMI}=$ body mass index; $\mathrm{SD}=$ standard deviation; $\mathrm{q} 25=0.25$ quantile; $\mathrm{q} 75=0.75$ quantile; $*=$ significant posthoc comparison $0-3$ months vs 3-6 months; ${ }^{\wedge}=$ significant post-hoc comparison $3-6$ months vs $6-12$ months. 
Table 2. Growth status according to age group 295

\begin{tabular}{|c|c|c|c|c|c|c|c|c|c|c|c|c|c|c|c|c|c|c|c|}
\hline \multirow[t]{3}{*}{ Categorical variable } & \multicolumn{6}{|c|}{$0-3$ months ( $n=124 \cdot 24.0 \%)$} & \multicolumn{6}{|c|}{ 3-6 months $(n=131 ; 25.3 \%)$} & \multicolumn{6}{|c|}{ 6-12 months ( $n=262 ; 50.7 \%)$} & \multirow[t]{3}{*}{$p$ value } \\
\hline & \multicolumn{2}{|c|}{ severe } & \multicolumn{2}{|c|}{ moderate } & \multicolumn{2}{|c|}{ mild } & \multicolumn{2}{|c|}{ severe } & \multicolumn{2}{|c|}{ moderate } & \multicolumn{2}{|c|}{ mild } & \multicolumn{2}{|c|}{ severe } & \multicolumn{2}{|c|}{ moderate } & \multicolumn{2}{|c|}{ mild } & \\
\hline & $n$ & $\%$ & $n$ & $\%$ & $n$ & $\%$ & $n$ & $\%$ & $n$ & $\%$ & $n$ & $\%$ & $n$ & $\%$ & $n$ & $\%$ & $n$ & $\%$ & \\
\hline $\begin{array}{l}\text { Stunting } \\
\text { (Length for age) }\end{array}$ & 6 & 4.8 & 20 & 16.1 & 38 & 30.7 & 8 & 6.1 & 20 & 15.3 & 39 & 29.8 & 30 & 11.5 & 40 & 15.3 & 75 & 28.6 & 0.662 \\
\hline $\begin{array}{l}\text { Wasting } \\
\text { (Weight for length) }\end{array}$ & 2 & 1.6 & 4 & 3.2 & 40 & 32.3 & 1 & 0.8 & 6 & 4.6 & 31 & 23.7 & 6 & 2.3 & 14 & 5.3 & 72 & 27.5 & 0.345 \\
\hline $\begin{array}{l}\text { Wasting } \\
\text { (BMI for age)* }\end{array}$ & 14 & 11.3 & 13 & 10.5 & 46 & 37.1 & 3 & 2.3 & 12 & 9.2 & 36 & 27.5 & 10 & 3.8 & 26 & 9.9 & 73 & 27.9 & 0.002 \\
\hline $\begin{array}{l}\text { Under weight } \\
\text { (Weight for age)* }\end{array}$ & 11 & 8.9 & 16 & 12.9 & 43 & 34.7 & 6 & 4.6 & 13 & 9.9 & 28 & 21.4 & 10 & 3.8 & 35 & 13.4 & 73 & 27.9 & 0.004 \\
\hline
\end{tabular}

$2980-3$ months $=$ from 1 day to 3 completed months, $3-6$ months $=$ from 3 months +1 day to 6 completed months, $6-12$ months $=$ from 6 months +1 day to 12 completed months, severe $=$ below $3 \mathrm{SD}$, moderate $=$ between -3 and $-2 \mathrm{SD}$, mild $=$ between -2 and $-1 \mathrm{SD}, \mathrm{BMI}=$ body mass index; 
304 Table 3. Effect of salt consumption on growth indexes (model adjusted for age, $n=235$, 6-12 305 months)

306

\begin{tabular}{|c|c|c|c|c|c|c|c|c|c|c|c|c|}
\hline \multirow{3}{*}{$\begin{array}{l}\text { Variable } \\
\begin{array}{l}\text { Length for age } \\
\text { (z-score) }\end{array}\end{array}$} & \multicolumn{4}{|c|}{ Intercept } & \multicolumn{4}{|c|}{ Salt } & \multicolumn{4}{|c|}{ Age (months) } \\
\hline & \multirow{2}{*}{$\frac{b}{-0.717}$} & \multicolumn{2}{|c|}{$(95 \% \mathrm{Cl})$} & \multirow{2}{*}{$\begin{array}{c}\text { p-value } \\
0.162\end{array}$} & \multirow{2}{*}{$\frac{b}{0.271}$} & \multicolumn{2}{|c|}{$(95 \% \mathrm{Cl})$} & \multirow{2}{*}{$\begin{array}{c}\text { p-value } \\
0.416\end{array}$} & \multirow{2}{*}{$\frac{b}{-0.087}$} & \multicolumn{2}{|c|}{$(95 \%$ Cl) } & \multirow{2}{*}{$\begin{array}{c}p \text {-value } \\
0.072\end{array}$} \\
\hline & & -1.718 & 0.284 & & & -0.381 & 0.922 & & & -0.181 & 0.007 & \\
\hline $\begin{array}{l}\text { Weight for length } \\
\text { (z-score) }\end{array}$ & -0.217 & -1.133 & 0.699 & 0.643 & -0.637 & -1.232 & $\overline{-}$ & 0.037 & 0.007 & -0.079 & 0.093 & 0.872 \\
\hline $\begin{array}{l}\text { BMI for age } \\
\text { (z-score) }\end{array}$ & -0.710 & -1.637 & 0.218 & 0.135 & -0.650 & -1.253 & $\begin{array}{c}- \\
0.046\end{array}$ & 0.036 & 0.060 & -0.027 & 0.148 & 0.175 \\
\hline $\begin{array}{l}\text { Weight for age } \\
\text { (z-score) }\end{array}$ & -0.467 & $-1.263 \mid$ & 0.329 & 0.251 & -0.427 & -0.945 & 0.091 & 0.107 & -0.002 & -0.077 & 0.073 & 0.958 \\
\hline
\end{tabular}

307
308
309

12

URL: http://mc.manuscriptcentral.com/cijf Email: daniele.delrio@unipr.it 
1

2

3

4

5

6

7

8

9

10

11

12

13

14

15

16

17

18

19

20

21

22

23

24

25

26

27

28

29

30

31

32

33

34

35

36

37

38

39

40

41

42

43

44

45

46

47

48

49

50

51

52

53

54

55

56

57

58

59

60
310 Table 4. Effect of adult food consumption on growth indexes (model adjusted for age, $n=235,6-12$ 311 months).

312

313

314

315

316

\begin{tabular}{|c|c|c|c|c|c|c|c|c|c|c|c|c|}
\hline \multirow{3}{*}{$\begin{array}{l}\text { Variable } \\
\begin{array}{l}\text { Length for age (z- } \\
\text { score) }\end{array}\end{array}$} & \multicolumn{4}{|c|}{ Intercept } & \multicolumn{4}{|c|}{ Adult food } & \multicolumn{4}{|c|}{ Age (months) } \\
\hline & \multirow{2}{*}{$\begin{array}{l}b \\
-0.757\end{array}$} & \multicolumn{2}{|c|}{$(95 \% \mathrm{Cl})$} & \multirow{2}{*}{\begin{tabular}{|l|}
$p$-value \\
0.109 \\
\end{tabular}} & \multirow{2}{*}{$\begin{array}{l}b \\
0.404\end{array}$} & \multicolumn{2}{|c|}{$(95 \% \mathrm{Cl})$} & \multirow{2}{*}{$\begin{array}{l}p \text {-value } \\
0.075\end{array}$} & \multirow{2}{*}{$\begin{array}{l}b \\
-0.090\end{array}$} & \multicolumn{2}{|c|}{$(95 \% \mathrm{Cl})$} & \multirow{2}{*}{\begin{tabular}{|l|}
$p$-value \\
0.059
\end{tabular}} \\
\hline & & \begin{tabular}{|l|}
-1.680 \\
\end{tabular} & 0.165 & & & -0.038 & 0.846 & & & -0.183 & 0.003 & \\
\hline $\begin{array}{l}\text { Weight for length } \\
\text { (z-score) }\end{array}$ & -0.342 & -1.186 & 0.501 & 0.427 & -0.560 & -0.964 & -0.156 & 0.007 & 0.006 & -0.079 & \begin{tabular}{|l|}
0.091 \\
\end{tabular} & 0.898 \\
\hline $\begin{array}{l}\text { BMI for age (z- } \\
\text { score) }\end{array}$ & -0.827 & \begin{tabular}{|l|}
-1.681 \\
\end{tabular} & 0.026 & 0.058 & -0.589 & -0.998 & -0.180 & 0.005 & 0.059 & -0.027 & 0.145 & 0.177 \\
\hline $\begin{array}{l}\text { Weight for age (z- } \\
\text { score) }\end{array}$ & -0.649 & \begin{tabular}{|l|}
-1.389 \\
\end{tabular} & 0.091 & 0.087 & -0.202 & -0.557 & 0.152 & 0.264 & -0.007 & -0.082 & 0.067 & 0.851 \\
\hline
\end{tabular}

3
4
5
6

URL: http://mc.manuscriptcentral.com/cijf Email: daniele.delrio@unipr.it 
$317 \quad$ Figure legend

319 Figure 1. A room of an elementary school from a remote village turned into a day-clinic for

320 data collection. On the front-left the infantometer used for measurements of babies. On the right a

321 group of mothers.

323 Figure 2. Graphical representation of anthropometric characteristics (z-scores) according to

324 age group. Boxplot explanation: upper horizontal line of box $=75$ th percentile; lower horizontal

325 line of box $=25$ th percentile; horizontal bar within box $=$ median, square within box = mean;

326 vertical lines out of the box $=$ minimum and maxim. 
Table 1. Descriptive statistics of anthropometric characteristics (raw and z-score) according to age group

\begin{tabular}{|c|c|c|c|c|c|c|c|c|c|c|c|c|c|c|c|c|}
\hline \multirow[t]{2}{*}{$\begin{array}{c}\text { Continuous } \\
\text { variable }\end{array}$} & \multicolumn{5}{|c|}{$0-3$ months ( $n=124 ; 24.0 \%$ ) } & \multicolumn{5}{|c|}{ 3-6 months ( $n=131 ; 25.3 \%$ ) } & \multicolumn{6}{|c|}{ 6-12 months ( $\mathrm{n}=262 ; 50.7 \%)$} \\
\hline & mean & SD & median & $\mathrm{q} 25$ & q75 & mean & SD & median & $\mathrm{q} 25$ & q75 & mean & SD & median & $\mathrm{q} 25$ & q75 & p-value \\
\hline Length $(\mathrm{cm})$ & 54.5 & 3.5 & 54.5 & 52.0 & 57.0 & 61.1 & 3.4 & 61.0 & 59.5 & 63.0 & 68.2 & 4.1 & 68.0 & 65.0 & 71.0 & $<0.0001$ \\
\hline Weight (kg) & 4.2 & 0.8 & 4.2 & 3.6 & 4.7 & 6.0 & 1.0 & 5.9 & 5.4 & 6.6 & 7.5 & 1.1 & 7.4 & 6.7 & 8.1 & $<0.0001$ \\
\hline BMI $\left(\mathrm{kg} / \mathrm{m}^{2}\right)$ & 13,8 & 1.6 & 13.9 & 12.5 & 15.1 & 16.0 & 1.6 & 16.0 & 14.9 & 16.8 & 16.0 & 1.8 & 15.8 & 14.9 & 16.9 & $<0.0001$ \\
\hline $\begin{array}{l}\text { Length for age } \\
\text { (z-score) }\end{array}$ & -1.01 & 1.43 & -1.02 & -1.89 & -0.16 & -1.09 & 1.38 & -1.14 & -1.86 & -0.29 & $\begin{array}{l}-1.32 \\
\end{array}$ & 1.43 & -1.21 & -2.09 & -0.52 & 0.0864 \\
\hline $\begin{array}{l}\text { Weight for length } \\
\text { (z-score) } * \wedge\end{array}$ & -0.88 & 1.24 & -0.97 & -1.54 & -0.11 & -0.43 & 1.13 & -0.31 & -1.21 & 0.27 & -0.71 & 1.28 & -0.79 & -1.44 & 0.05 & 0.0115 \\
\hline $\begin{array}{l}\text { BMl for age } \\
\text { (z-score)* }\end{array}$ & -1.32 & 1.13 & -1.18 & -1.89 & -0.66 & -0.72 & 1.16 & -0.55 & -1.39 & -0.04 & -0.73 & 1.29 & -0.81 & -1.47 & 0.01 & $<0.001$ \\
\hline $\begin{array}{l}\text { Weight for age } \\
\text { (z-score)* }\end{array}$ & -1.17 & 1.27 & -1.09 & -1.88 & -0.48 & -0.81 & 1.23 & -0.77 & -1.28 & -0.02 & -0.90 & 1.14 & -0.88 & -1.67 & -0.11 & 0.0474 \\
\hline
\end{tabular}

0-3 months = from 1 day to 3 completed months, $3-6$ months $=$ from 3 months +1 day to 6 completed months, $6-12$ months = from 6 months +1 day to 12 completed months, $\mathrm{BMI}=$ body mass index; $\mathrm{SD}=$ standard deviation; $\mathrm{q} 25=0.25$ quantile; $\mathrm{q} 75=0.75$ quantile; ${ }^{*}=$ significant post-hoc comparison $0-3$ months vs 3-6 months; ^ = significant post-hoc comparison 3-6 months vs 6-12 months. 
Table 2. Growth status according to age group.

\begin{tabular}{|c|c|c|c|c|c|c|c|c|c|c|c|c|c|c|c|c|c|c|c|}
\hline \multirow[t]{3}{*}{ Categorical variable } & \multicolumn{6}{|c|}{$0-3$ months ( $n=124 ; 24.0 \%)$} & \multicolumn{6}{|c|}{ 3-6 months ( $n=131 ; 25.3 \%)$} & \multicolumn{6}{|c|}{$6-12$ months $(n=262 ; 50.7 \%)$} & \multirow[t]{3}{*}{$p$ value } \\
\hline & \multicolumn{2}{|c|}{ severe } & \multicolumn{2}{|c|}{ moderate } & \multicolumn{2}{|c|}{ mild } & \multicolumn{2}{|c|}{ severe } & \multicolumn{2}{|c|}{ moderate } & \multicolumn{2}{|c|}{ mild } & \multicolumn{2}{|c|}{ severe } & \multicolumn{2}{|c|}{ moderate } & \multicolumn{2}{|c|}{ mild } & \\
\hline & $\mathbf{n}$ & $\%$ & $n$ & $\%$ & $n$ & $\%$ & $n$ & $\%$ & $n$ & $\%$ & $n$ & $\%$ & $\mathrm{n}$ & $\%$ & $n$ & $\%$ & $n$ & $\%$ & \\
\hline $\begin{array}{l}\text { Stunting } \\
\text { (Length for age) }\end{array}$ & 6 & 4.8 & 20 & 16.1 & 38 & 30.7 & 8 & 6.1 & 20 & 15.3 & 39 & 29.8 & 30 & 11.5 & 40 & 15.3 & 75 & 28.6 & 0.662 \\
\hline $\begin{array}{l}\text { Wasting } \\
\text { (Weight for length) }\end{array}$ & 2 & 1.6 & 4 & 3.2 & 40 & 32.3 & 1 & 0.8 & 6 & 4.6 & 31 & 23.7 & 6 & 2.3 & 14 & 5.3 & 72 & 27.5 & 0.345 \\
\hline $\begin{array}{l}\text { Wasting } \\
\text { (BMI for age)* }\end{array}$ & 14 & 11.3 & 13 & 10.5 & 46 & 37.1 & 3 & 2.3 & 12 & 9.2 & 36 & 27.5 & 10 & 3.8 & 26 & 9.9 & 73 & 27.9 & 0.002 \\
\hline $\begin{array}{l}\text { Under weight } \\
\text { (Weight for age)* }\end{array}$ & 11 & 8.9 & 16 & 12.9 & 43 & 34.7 & 6 & 4.6 & 13 & 9.9 & 28 & 21.4 & 10 & 3.8 & 35 & 13.4 & 73 & 27.9 & 0.004 \\
\hline
\end{tabular}

0-3 months = from 1 day to 3 completed months, 3-6 months = from 3 months +1 day to 6 completed months, $6-12$ months = from 6 months +1 day to 12 completed months, severe = below $-3 \mathrm{SD}$, moderate = between -3 and $-2 \mathrm{SD}$, mild = between -2 and $-1 \mathrm{SD}, \mathrm{BMI}=$ body mass index; $S \mathrm{SD}=\mathrm{standard}$ deviation; * = significant post-hoc comparison 0-3 months vs 3-6 months. 
Table 3. Effect of salt consumption on growth indexes( model adjusted for age, $n=235,6-12$ months)

\begin{tabular}{|c|c|c|c|c|c|c|c|c|c|c|c|c|}
\hline \multirow{3}{*}{\begin{tabular}{l}
\multicolumn{1}{c}{ Variable } \\
Length for age \\
(z-score)
\end{tabular}} & \multicolumn{4}{|c|}{ Intercept } & \multicolumn{4}{|c|}{ Salt } & \multicolumn{4}{|c|}{ Age (months) } \\
\hline & \multirow{2}{*}{$\frac{b}{-0.717}$} & \multicolumn{2}{|c|}{$(95 \%$ Cl) } & \multirow{2}{*}{$\begin{array}{c}p \text {-value } \\
0.162\end{array}$} & \multirow{2}{*}{$\frac{b}{0.271}$} & \multicolumn{2}{|c|}{$(95 \% \mathrm{Cl})$} & \multirow{2}{*}{$\frac{p \text {-value }}{0.416}$} & \multirow{2}{*}{$\frac{b}{-0.087}$} & \multicolumn{2}{|c|}{$(95 \% \mathrm{Cl})$} & \multirow{2}{*}{$\begin{array}{c}p \text {-value } \\
0.072\end{array}$} \\
\hline & & -1.718 & 0.284 & & & -0.381 & 0.922 & & & -0.181 & 0.007 & \\
\hline $\begin{array}{l}\text { Weight for length } \\
\text { (z-score) }\end{array}$ & -0.217 & -1.133 & 0.699 & 0.643 & -0.637 & .232 & $\begin{array}{c}- \\
0.041\end{array}$ & 0.037 & 0.007 & -0.079 & 0.093 & 0.872 \\
\hline $\begin{array}{l}\text { BMI for age } \\
\text { (z-score) }\end{array}$ & -0.710 & -1.637 & 0.218 & 0.135 & -0.650 & -1.253 & $\begin{array}{c}- \\
0.046\end{array}$ & 0.036 & 0.060 & -0.027 & 0.148 & 0.175 \\
\hline $\begin{array}{l}\text { Weight for age } \\
\text { (z-score) }\end{array}$ & -0.467 & -1.263 & 0.329 & 0.251 & -0.427 & -0.945 & 0.091 & 0.107 & -0.002 & -0.077 & 0.073 & 0.958 \\
\hline
\end{tabular}


Table 4. Effect of adult food consumption on growth indexes. (model adjusted for age, $n=235,6-12$ months).

\begin{tabular}{|c|c|c|c|c|c|c|c|c|c|c|c|c|}
\hline \multirow{3}{*}{$\begin{array}{l}\text { Variable } \\
\text { Length for age (z- } \\
\text { score) }\end{array}$} & \multicolumn{4}{|c|}{ Intercept } & \multicolumn{4}{|c|}{ Adult food } & \multicolumn{4}{|c|}{ Age (months) } \\
\hline & \multirow{2}{*}{$\begin{array}{l}b \\
-0.757\end{array}$} & \multicolumn{2}{|c|}{$(95 \% \mathrm{Cl})$} & \multirow{2}{*}{$\begin{array}{l}p \text {-value } \\
0.109\end{array}$} & \multirow{2}{*}{$\begin{array}{l}b \\
0.404\end{array}$} & \multicolumn{2}{|c|}{$(95 \%$ CI) } & \multirow{2}{*}{$\begin{array}{l}p \text {-value } \\
0.075\end{array}$} & \multirow{2}{*}{$\begin{array}{l}b \\
-0.090\end{array}$} & \multicolumn{2}{|c|}{$(95 \%$ CI) } & \multirow{2}{*}{\begin{tabular}{|l|}
$p$-value \\
0.059
\end{tabular}} \\
\hline & & -1.680 & 0.165 & & & -0.038 & 0.846 & & & -0.183 & 0.003 & \\
\hline $\begin{array}{l}\text { Weight for length } \\
\text { (z-score) }\end{array}$ & -0.342 & -1.186 & 0.501 & 0.427 & -0.560 & -0.964 & -0.156 & 0.007 & 0.006 & $\mid-0.079$ & 0.091 & 0.898 \\
\hline $\begin{array}{l}\text { BMI for age (z- } \\
\text { score) }\end{array}$ & -0.827 & -1.681 & 0.026 & 0.058 & -0.589 & -0.998 & -0.180 & 0.005 & 0.059 & -0.027 & 0.145 & 0.177 \\
\hline $\begin{array}{l}\text { Weight for age (z- } \\
\text { score) }\end{array}$ & -0.649 & -1.389 & 0.091 & 0.087 & -0.202 & -0.557 & 0.152 & 0.264 & -0.007 & -0.082 & 0.067 & 0.851 \\
\hline
\end{tabular}


Figure 1. A room of an elementary school from a remote village turned into a day-clinic for data collection. On the front-left the infantometer used for measurements of babies. On the right a group of mothers. Figure 1

$245 \times 164 \mathrm{~mm}(300 \times 300 \mathrm{DPI})$ 

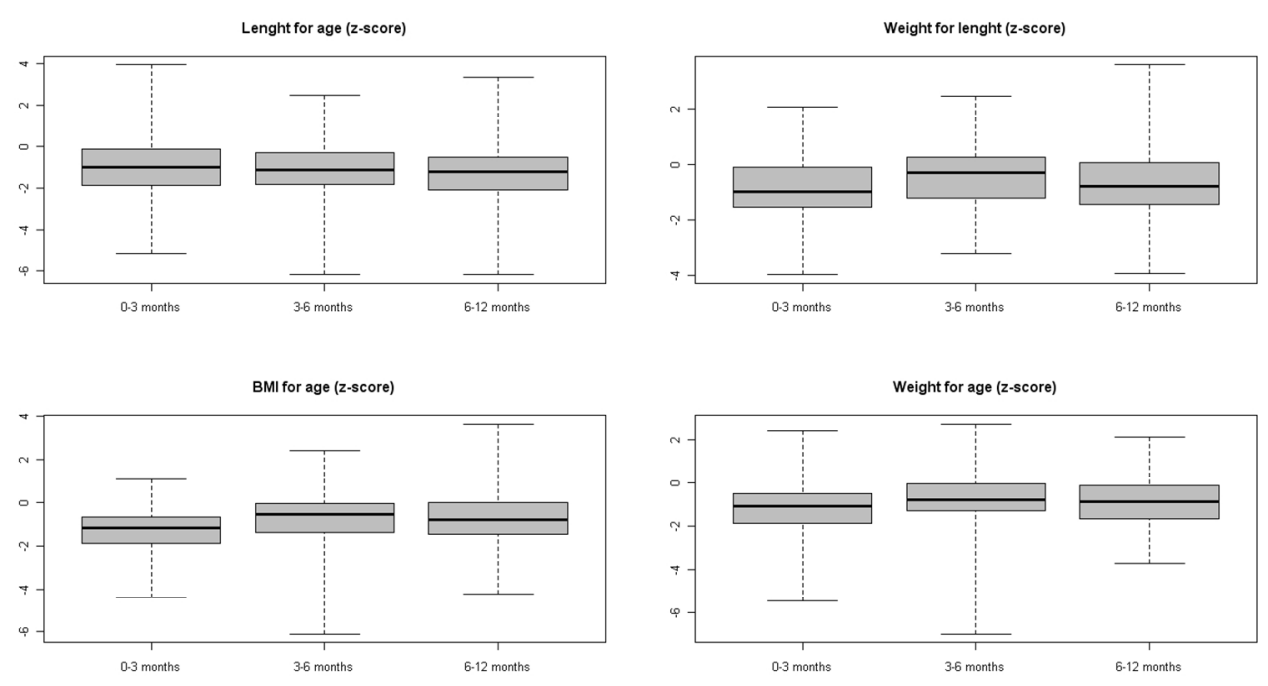

Figure 2. Graphical representation of anthropometric characteristics (z-scores) according to age group. Boxplot explanation: upper horizontal line of box $=75$ th percentile; lower horizontal line of box $=25$ th percentile; horizontal bar within box = median, square within box = mean; vertical lines out of the box $=$ minimum and maxim.

Figure 2

$508 \times 281 \mathrm{~mm}(72 \times 72 \mathrm{DPI})$ 